\title{
Pleurozium schreberi as bioindicator of mercury pollution in heavily industrialized region
}

\author{
Aleksandra Samecka-Cymerman • Grzegorz Kosior • \\ Krzysztof Kolon • Bronislaw Wojtuń • \\ Krzysztof Zawadzki • Andrzej Rudecki • \\ Alexander J. Kempers
}

Received: 5 October 2012 / Accepted: 1 April 2013 /

Published online: 19 April 2013

(C) The Author(s) 2013. This article is published with open access at Springerlink.com

\begin{abstract}
This research is continuation of the investigation of metal accumulation in native and transplanted moss Pleurozium schreberi in the most industrialized and affected region in Poland (Upper Silesia). We tested the hypotheses that in Upper Silesia transplants of $P$. schreberi may be used in a 90 days bioindication experiment in case native specimens are absent; a 90 days exposure of transplanted P. schreberi was long enough for evaluation of $\mathrm{Hg}$ pollution of the environment. An assay was carried out with native mosses at 27 polluted sites and mosses from an uncontaminated control site transplanted to the same 27 polluted sites. . schreberi collected from the same sites as classified for more and less polluted basing on $\mathrm{Pb}$ and $\mathrm{Zn}$ concentrations show quite different pattern of pollution with mercury; The accumulation of $\mathrm{Hg}$ by the transplants increased much faster in the first 45 days of the experiment (accumulation factor 1.5-6.7; mean 3.4 \pm 0.5 ) in comparison with the second period from day 45 to 90 (accumulation factor 1.0-1.6; mean 1.2 \pm 0.1 ). The 90 days exposure of transplanted P. schreberi was long enough for evaluation of $\mathrm{Hg}$ pollution of the
\end{abstract}

\footnotetext{
A. Samecka-Cymerman $(\bowtie) \cdot$ G. Kosior $\cdot$ K. Kolon $\cdot$ B. Wojtuń $\cdot$ K. Zawadzki $\cdot$ A. Rudecki Department of Ecology, Biogeochemistry and Environmental Protection,

Wrocław University, ul. Kanonia 6/8, 50-328 Wrocław, Poland

e-mail: sameckaa@biol.uni.wroc.pl

G. Kosior

e-mail: grzegorz.kosior@biol.uni.wroc.pl

K. Kolon

e-mail: kolonk@biol.uni.wroc.pl

B. Wojtuń

e-mail: bronislaw.wojtun@biol.uni.wroc.pl
}

\author{
A. J. Kempers \\ Department of Environmental Sciences, Radboud University, Huygens building, \\ Heyendaalseweg 135, 6525 AJ Nijmegen, The Netherlands \\ e-mail: L.Kempers@science.ru.nl
}


environment. Transplants of $P$. schreberi may be used in a 90 days bioindication experiment in case native specimens are absent.

Keywords Bioindication · Mercury · Pleurozium schreberi · Pollution · Upper Silesia · Transplant

\section{Introduction}

One of the major threats to human well-being is associated with mercury. Therefore, this substance is primarily targeted by international legislative bodies. Once in the air, mercury can be widely dispersed and transported over longer distances and after deposition contribute in this way to environmental pollution (Balarama Krishna et al. 2003). Among anthropogenic sources of mercury emission, the most important ones are: hard and brown coal combustion in power (and heating) plants and chlorine production using the mercury method. Upper Silesia (centered around the city of Katowice, Fig. 1) is one of the most urbanized, industrialized and polluted regions of Poland, characterized by hard coal mines, zinc and lead ore mining, smelters, iron and steel metallurgical works, nonferrous metal processing, chemical plants, and power stations (Pyta et al. 2009). Both the exploitation of mineral resources and industrial activity have caused high levels of air pollution and soil contamination with mercury for example. Bryophytes have been described in the literature as able to intercept, retain and accumulate pollutants (Zechmeister et al. 2003; Kolon et al. 2010). Fernándèz et al. (2000) assume that it is well known that plants have a capacity to adapt to certain environmental conditions. Therefore, native mosses should accumulate

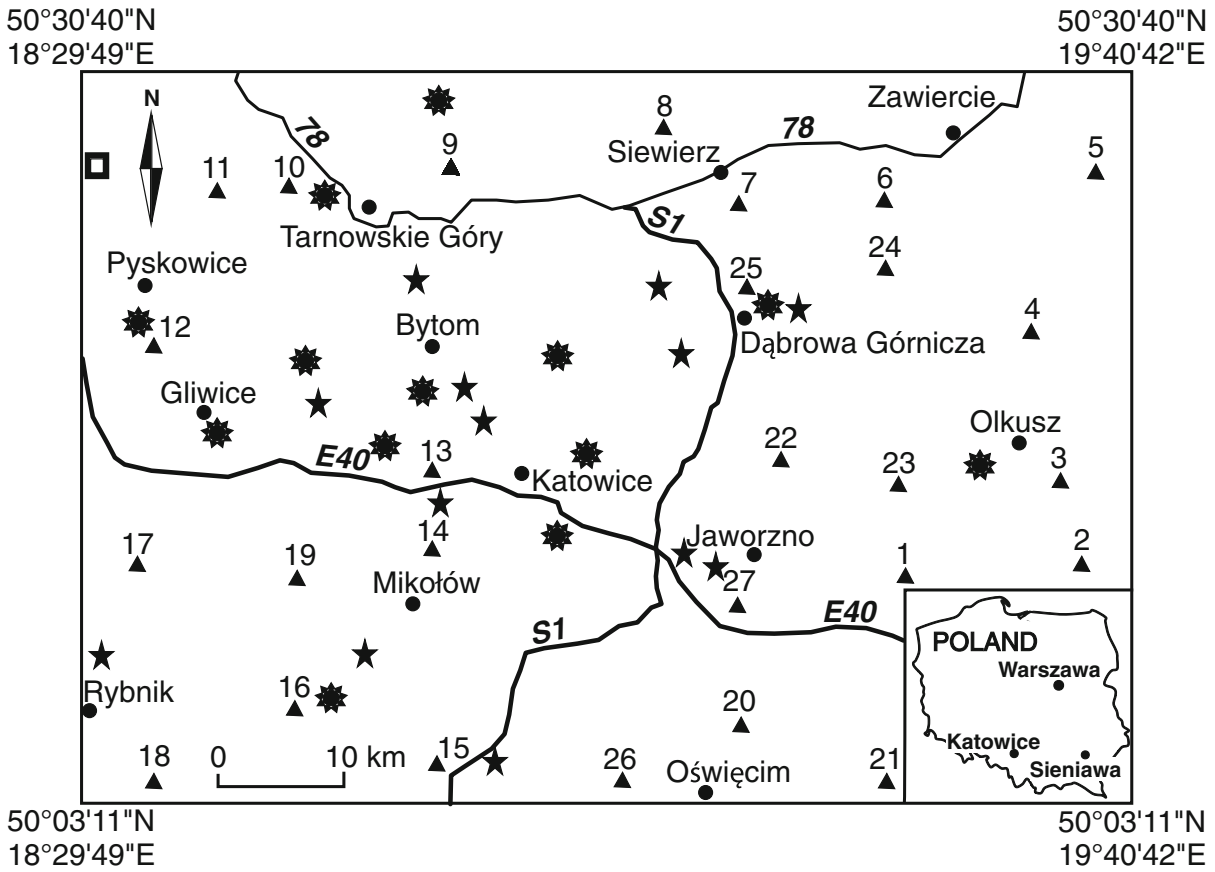

Fig. 1 Location of the investigated area: sampling sites $\boldsymbol{\Delta}$, smelters $\boldsymbol{*}$, power plants $\star$, chemical plants 
significantly less heavy metals than the same moss species transplanted to a polluted environment. We based our research on the simplified and modified bioindication method by Fernándèz et al. (2000) and continued the investigation (Kosior et al. 2010) of metal pollution in Upper Silesia. Mercury concentration in Pleurozium schreberi, transplanted from an unpolluted control site to an extremely polluted area in Upper Silesia, was compared with the bioconcentration of mercury in this species which grew naturally at the contaminated and control sites. We tested the hypotheses that in Upper Silesia transplants of $P$. schreberi may be used in a 90 days bioindication experiment in case native specimens are absent; a 90 days exposure of transplanted $P$. schreberi was long enough for evaluation of $\mathrm{Hg}$ pollution of the environment.

\section{Materials and methods}

We selected the terrestrial, carpet forming, pleurocarpous and ectohydric moss $P$. schreberi because it occurs widely in the Northern Hemisphere, including Poland. This species has been used successfully in recent decades and has proved to be a suitable bioindicator of inorganic substances and, therefore, has been widely used to map and control heavy metal pollution in European countries (Niemelä et al. 2007; Kosior et al. 2010).

\subsection{Sampling design}

Native moss samples in the polluted area were collected within a rectangular area of $80 \times$ $60 \mathrm{~km}^{2}$ (Fig. 1). This area was divided into 48 squares of $10 \times 10 \mathrm{~km}^{2}$ (Kosior et al. 2010). From these 48 squares, 27 were selected randomly. Within the central part (an area of $50 \times$ $50 \mathrm{~m}^{2}$ ) of each of the selected 27 squares, $5 \mathrm{sub}$-squares of $2 \times 2 \mathrm{~m}^{2}$, covered with P. schreberi, were selected randomly. Only the green parts of $P$. schreberi were sampled together with the topsoil $(0-5 \mathrm{~cm})$ from the anthropogenic sites and $0-5 \mathrm{~cm}$ from the control soil after removal of the L, F and $\mathrm{H}$ layers (having a total thickness of about $4 \mathrm{~cm}$ ). Each plant and soil sample consisted of a mixture of three sub-samples. In each of these five $2 \times 2 \mathrm{~m}^{2}$ sub-squares, five randomly chosen places were cleaned from vegetation into which patches $\left(20 \times 20 \mathrm{~cm}^{2}\right)$ of P. schreberi (originating from the control site) were transplanted. The remaining part of the $2 \times 2 \mathrm{~m}^{2}$ sub-square was left covered with native $P$. schreberi. The total number of samples was $N=28 \times 5=140$, including the five samples from the unpolluted control site between Sieniawa and Adamowka, $200 \mathrm{~km}$ east of Katowice and $112 \mathrm{~km}$ south of Lublin (50 $13^{\prime} 03^{\prime \prime}$ $\mathrm{N} ; 22^{\circ} 43^{\prime} 53^{\prime \prime} \mathrm{E}$ ). Also within the control site, five $2 \times 2 \mathrm{~m}^{2}$ sub-squares were selected randomly into which patches $\left(20 \times 20 \mathrm{~cm}^{2}\right)$ of $P$. schreberi were transplanted in the same way as in the Upper Silesia area in order to control the influence of transplantation on metal accumulation. In the same sampling site of the control area, five samples of the topsoil ( $0-5 \mathrm{~cm}$, each sample consisted of a mixture of three sub-samples) were taken, giving a total number of samples of $N=28 \times 5=140$. The experiment lasted 90 days during which samples of native and transplanted $P$. schreberi were collected at time 0 (represented by the value in the moss at the control site from where the transplanted mosses were collected), 45 and 90 days. The exposure period was based on the experiments of Fernándèz and Carballeira (2001), Brown and Beckett (1985) and Brown and Brumelis (1996) with transplanted Scleropodium purum, Rhytidiadelphus squarrosus and Hylocomium splendens respectively. In each site the moss samples were taken in five replications (each replication consisted of one patch of $20 \mathrm{~cm} \times 20 \mathrm{~cm}$ ). From these patches samples were collected for determination of mercury at day 45 (2 patches of $10 \times 10 \mathrm{~cm}$ in 5 replications, $N=10)$ and at day 90 
( 2 remaining patches of $10 \times 10 \mathrm{~cm}$ in 5 replications, $N=10$ ). Each collected sample consisted of many moss individuals being representative for the whole site.

As required by the rules set by the Environmental Monitoring and Data Group (Markert et al. 1996) and within the European Heavy Metal Survey (ICP Vegetation 2005), the collected moss had not been exposed directly to canopy throughfall. Dead material, soil particles and litter were manually removed from the moss samples. The moss samples were not washed (Markert et al. 1996; ICP Vegetation 2005).

\subsection{Plant and soil analysis}

Plant and soil samples were dried at $50{ }^{\circ} \mathrm{C}$ to constant weight and homogenized in a laboratory mill. According to our previous experiment as well as Fernándèz et al. (2000), Balarama Krishna et al. (2003) and Gupta et al. (2010) this temperature was low enough to prevent significant loss of mercury. Mercury was analysed using an AMA 254 Advanced Mercury Analyser. The accuracy of the methods for the determination of $\mathrm{Hg}$ was checked against M2 and M3 certified standard moss reference materials (Finnish Forest Research Institute) and an RTH 907 Dutch Anthropogenic Soil (WEPAL) certified reference material (Table 1).

\subsection{Statistical analysis}

Differences between the sampling sites in terms of $\mathrm{Hg}$ concentrations in soil and in the moss specimens were evaluated by ANOVA on log-transformed data to obtain normal distribution of features according to Zar (1999). The normality of the analysed features was checked using Shapiro-Wilk's W test, and the homogeneity of variances was checked after transformation using the Brown-Forsythe test. All calculations were done with Statistica 10 software (StatSoft 2011).

\section{Results and discussion}

The soil and P. schreberi samples differed significantly in terms of mercury concentrations (ANOVA, $p<0.05)$. The $\mathrm{Hg}$ concentrations in the control soil $\left(0.02-0.03 \mathrm{mg} \mathrm{kg}{ }^{-1}\right)$ were typical average values (Kabata-Pendias 2001) and were significantly lower ( $t$ test, $P<0.001$ ) than in the Upper Silesia soil $\left(0.04-0.3 \mathrm{mg} \mathrm{kg}^{-1}\right)$. The upper $\mathrm{Hg}$ concentration in the investigated area was also higher than $0.10 \mathrm{mg} \mathrm{kg}^{-1}$ established by Adrianek and Skowronek (2005) for Upper Silesia soil. Because mosses are used as biomonitors of atmospheric pollution, analysis of soil was treated as an additional information about the

Table 1 Analysis of reference plant and soil material

\begin{tabular}{|c|c|c|c|c|c|c|c|c|}
\hline \multirow[t]{2}{*}{ Element } & \multicolumn{4}{|c|}{$\begin{array}{l}\text { Moss M2 (Finnish Forest Research Institute) } \\
\text { standards }\end{array}$} & \multicolumn{4}{|c|}{$\begin{array}{l}\text { Moss M3 (Finnish Forest Research Institute) } \\
\text { standards }\end{array}$} \\
\hline & $\begin{array}{l}\text { Certified } \\
\mathrm{mg}^{-1} \mathrm{~kg}^{-1}\end{array}$ & Found & $\begin{array}{l}\text { Recovery } \\
(\%)\end{array}$ & $\mathrm{CV}$ & $\begin{array}{l}\text { Certified } \\
\mathrm{mg}^{-1} \mathrm{~kg}^{-1}\end{array}$ & Found & $\begin{array}{l}\text { Recovery } \\
(\%)\end{array}$ & $\mathrm{CV}$ \\
\hline $\mathrm{Hg}$ & $0.058 \pm 0.005$ & $0.058 \pm 0.003$ & 100 & 5.2 & $0.035 \pm 0.004$ & $0.036 \pm 0.003$ & 102.86 & 8.3 \\
\hline \multicolumn{9}{|c|}{ Dutch Anthropogenic Soil RTH907 } \\
\hline $\mathrm{Hg}$ & $1.14 \pm 0.13$ & $1.17 \pm 0.01$ & 102.63 & 0.85 & & & & \\
\hline
\end{tabular}


level of contamination of the environment. We based this on the assumptions of Mersch and Reichard (1998), Holoubek et al. (2000) and Sardans and Peñuelas (2005) that measuring concentrations of elements in plants is the best way to define the amount of elements available for accumulation and to determine the extent of environmental contamination (Čeburnis and Steinnes 2000).

The $\mathrm{Hg}$ concentrations in the moss $P$. schreberi from the control site (Table 2) were similar to those in P. schreberi $\left(0.03-0.04 \mathrm{mg} \mathrm{kg}^{-1}\right)$ from non-polluted Alaska mountains (Migaszewski et al. 2010), indicating that the control site we selected can be regarded as relatively free from the influence of anthropogenic pollution. Compared to the values of the control site, $\mathrm{Hg}$ concentrations were significantly higher in the native and transplanted plants from the Upper Silesia sites (Table 2, Figs. 2 and 3). Mercury concentrations found in native $P$. schreberi reflected emissions produced by heavy industry and transport in Upper Silesia reaching a value of $0.45 \mathrm{mg} \mathrm{kg}^{-1}$ at site 22 (Fig. 3). Site 22 together with sites 23 and 27 were influenced by the complex of two power stations near Jaworzno. However site 22 with the highest concentration of $\mathrm{Hg}$ also in soil $\left(0.3 \mathrm{mg} \mathrm{kg}{ }^{-1}\right)$ was situated in the direction of the prevailing west winds (Sztyler 2005) from the agglomerations of Katowice, Świętochłowice and Sosnowiec. This area is known from the wastes being the biggest source of mercury pollution in the whole Upper Silesia (Michalska 2010) and is an additional source of $\mathrm{Hg}$ upon the coal industry. Additionally sites 23 and 27 were separated from the power stations by forests. Other sites with increased $\mathrm{Hg}$ concentrations were situated in the vicinity of a chemical plant (site 11) and metal smelters as well as power stations (sites 12-14) (Fig. 3). Mercury is a natural component of coal, but despite its relatively small content of 100 to $150 \mu \mathrm{g} \mathrm{Hg} \mathrm{kg}^{-1}$, the combustion of hard coal contributes to a significant load of mercury in the environment. Especially the concentration of $\mathrm{Hg}$ in coals used in Upper Silesia is $0.08-0.15 \mathrm{mg} \mathrm{kg}{ }^{-1}$ what gives in fly ashes $0.09-0.65 \mathrm{mg} \mathrm{kg}^{-1}$ (Michalska 2010). The average monthly concentrations of the total mercury in Upper Silesia were in the range of 4.1 to $9.1 \mathrm{ng}^{-3}$. Elemental mercury presented $96 \%$ up to $99 \%$ of the total gaseous mercury concentration in the air (Pyta et al. 2009). Increased Hg concentrations also characterized plants at site 3 (Fig. 2) situated in the main $\mathrm{Zn}-\mathrm{Pb}$ ore mining and processing area located around Olkusz (Fig. 1) (Cabala et al. 2009). According to Bojakowska and Sokołowska (2002), exploitation of these ores brings up to the surface about $530 \mathrm{~kg}$ of $\mathrm{Hg}$ per year. According to Fernándèz et al. (2000), plants have a capacity to adapt to certain environmental conditions. His study proves that native moss in a polluted environment accumulate significantly less heavy metals than those of the same specimen transplanted from an unpolluted environment. Therefore, the transplanted specimen reflected a better level of contamination with metals as examined by the above-mentioned authors. Our results of $\mathrm{Hg}$ bioaccumulation were different.

In this investigation the concentration of $\mathrm{Hg}$ in the native plants from nearly all sites were always higher (Figs. 2 and 3) than in the transplanted mosses. This result indicates a possible adaptation mechanism which allowed $P$. schreberi to survive the accumulation of high mercury levels (Fernándèz et al. 2000). According to Shaw (1994) and Guschina and Harwood (2002), some specimens of mosses appear to have inherently a high level of metal tolerance, which permits them to colonize and thrive in metal-contaminated environments. The only exception was native moss at ten sites: 4-6, 8-9, 15, 18-19, 21, 26. These ten sites contained the lowest concentrations of $\mathrm{Hg}$ in the native P. schreberi and there was no difference in accumulated $\mathrm{Hg}$ between native and transplanted plants (Figs. 2 and 3). Throughout the exposure time, analysis of variance (ANOVA, $P<0.05$ ) showed no significant differences in $\mathrm{Hg}$ concentration in the native moss, whereas in the transplants the 


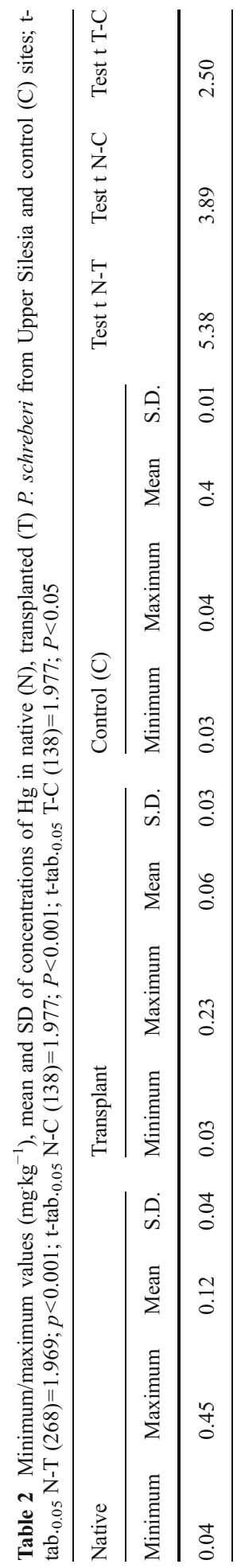


Figs. 2 and 3 Concentration of $\mathrm{Hg}$ in Pleurozium schreberi in Upper Silesia after 0-45-90 days of exposure in: 1) native moss $-\infty--$ and 2) transplanted moss $\longrightarrow$. The concentration of metals on day 0 in the transplanted Pleurozium schreberi is represented by the value in mosses at the control site from which the transplanted mosses were collected
2
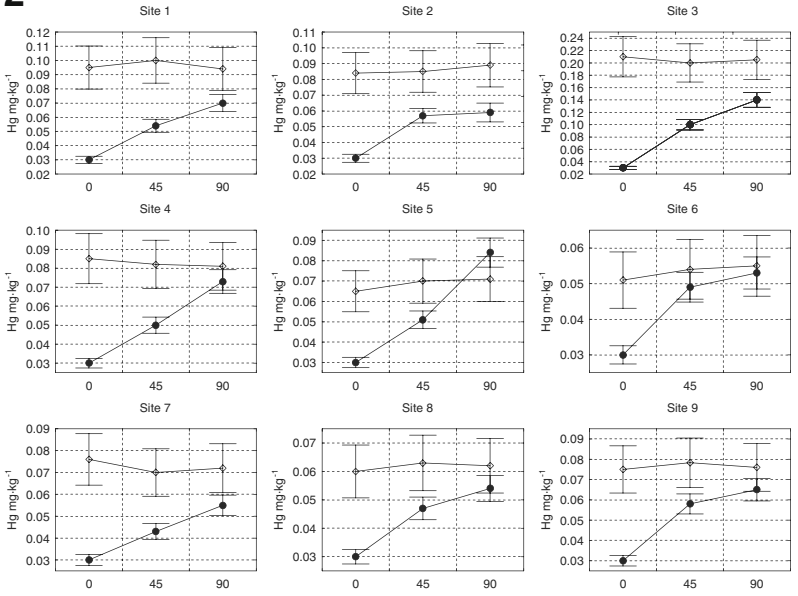

\section{3}
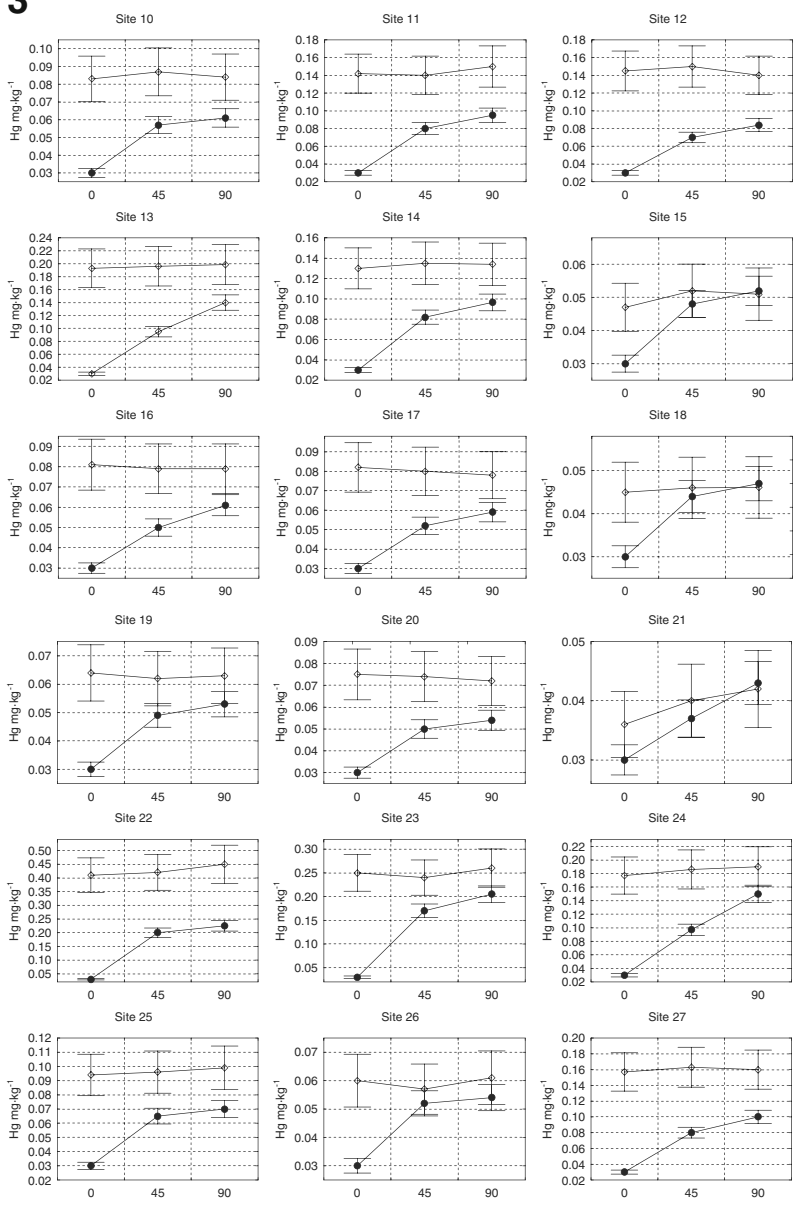
differences were significant between 0-45-90 days of the experiment. The accumulation of metals by the transplants calculated as a ratio of concentrations at 45 days $/ 0$ days and 90 days/45 days increased much faster in the first 45 days of the experiment (accumulation factor 1.5-6.7, mean 3.4 \pm 0.5 ) in comparison with the second period from day 45 to 90 (accumulation factor 1.0-1.6 mean 1.2 \pm 0.1 ). The accumulation was the highest for $\mathrm{Hg}$ in P. schreberi from sites 3, 11-14, 22-24 and 27 containing the highest $\mathrm{Hg}$ concentration in the soils. The ratio

$$
\mathrm{I}=\left[\left(\mathrm{C}_{\mathrm{N}}-\mathrm{C}_{\mathrm{N}-1}\right) / \mathrm{C}_{\mathrm{N}}\right] * 100 \%
$$

where $\mathrm{I}=$ percentage of increase in the concentration of $\mathrm{Hg}$ in relation to the concentration of this metal in transplants; $\mathrm{C}=$ concentration of $\mathrm{Hg} ; \mathrm{N}=$ time of measurement, $\mathrm{N}-1$ time of previous measurement) showed that $P$. schreberi from more polluted sites accumulated $68 \% \mathrm{Hg}$ after 45 days. The same percentage ratio for $P$. schreberi from the less polluted sites $1-2,4-10,15-21,25-26$ after 45 days was $43 \%$ (Fig. 4). There was no significant difference for this ratio after 90 days of exposure. In a similar experiment but with different elements $(\mathrm{Cr}$ and $\mathrm{Cu}$ ) Fernándèz and Carballeira (2001) also observed the highest level of bioconcentration in transplanted Scleropodium purum during the first 4 weeks, after which the accumulation tended to stabilize during the following 4 weeks, reaching a state of equilibrium. Similar results have been presented for the moss Rhytidiadelphus squarrosus by Brown and Beckett (1985) and for Hylocomium splendens by Brown and Brumelis (1996). These results suggest that the exposure period of 90 days in the present investigation was long enough to enable a comparison of bioconcentration in transplanted and native $P$. schreberi (Fernándèz et al. 2000).

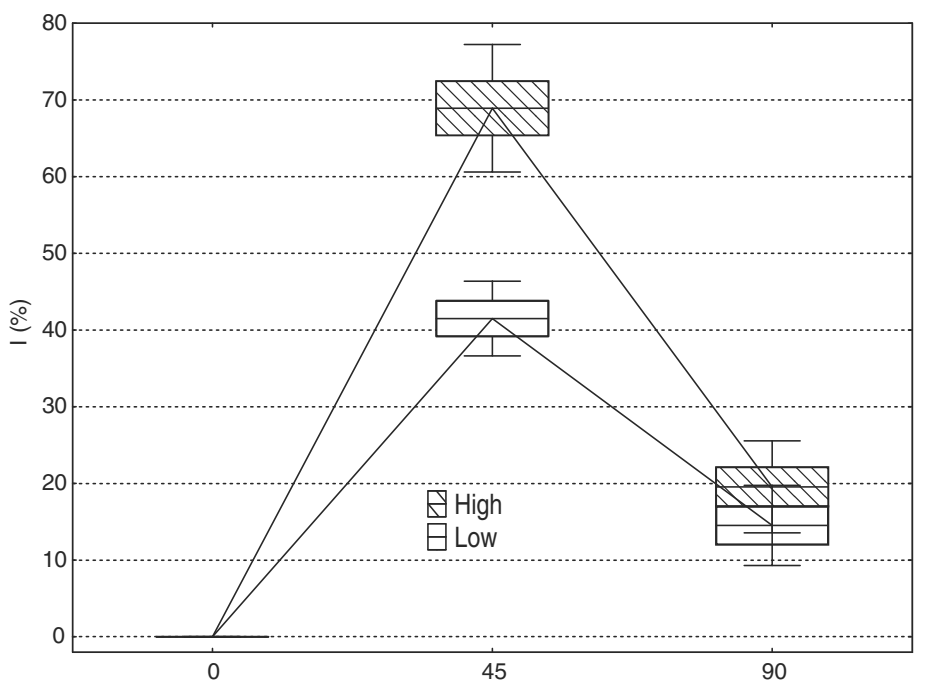

Fig. 4 Percentage of increase in the concentration of $\mathrm{Hg}$ in relation to the concentration of this metal in transplants $\mathrm{I}=\left[\left(\mathrm{C}_{\mathrm{N}}-\mathrm{C}_{\mathrm{N}-1}\right) / \mathrm{C}_{\mathrm{N}}\right] * 100 \%$ (where $\mathrm{I}=$ percentage of increase in the concentration of $\mathrm{Hg}$ in relation to the concentration of this metal in transplants; $\mathrm{C}=$ concentration of $\mathrm{Hg}$ and $\mathrm{N}=$ time of measurement; N-1 time of previous measurement) in transplants from more $\mathrm{Hg}$ polluted sites $(3,11-14$, 22-24, 27) and less $\mathrm{Hg}$ polluted sites (1-2, 4-10, 15-21, 25-26) 


\section{Conclusions}

The 90 days exposure of transplanted P. schreberi was long enough for the evaluation of $\mathrm{Hg}$ pollution of the environment; transplants of $P$. schreberi may be used in a 90 days bioindication experiment in case native specimens are absent.

Open Access This article is distributed under the terms of the Creative Commons Attribution License which permits any use, distribution, and reproduction in any medium, provided the original author(s) and the source are credited.

\section{References}

Adrianek, Z., Skowronek, K.: Gleby. Stan gleb w województwie śląskim w oparciu o wyniki badań przeprowadzonych przez Okręgową Stację Chemiczno-Rolniczą w Gliwicach [State of soil in Silesia basing on investigation of chemical-agricultural station in Gliwice]. In: Raport o stanie środowiska województwa śląskiego [Report of state of Silesia environment] 123-131 (2005)

Balarama Krishna, M.V., Karunasagar, D., Arunachalam, J.: Study of mercury pollution near a thermometer factory using lichens and mosses. Environ. Pollut. 124, 357-360 (2003)

Bojakowska, I., Sokołowska, G.: Rtęć w kopalinach wydobywanych w Polsce jako potencjalne źródło zanieczyszczenia środowiska [Mercury contamination during exploitation and processing of coal and ores as a potential source of environmental pollution in Poland]. Biuletyn PIG 394, 5-54 (2002)

Brown, D.H., Beckett, R.P.: Intracellular and extracellular uptake of cadmium by the moss Rhytidiadelphus squarrosus. Ann. Bot. Lond. 55, 179-188 (1985)

Brown, D.H., Brumelis, G.: A biomonitoring method using the cellular distribution of metals in moss. Sci. Total. Environ. 187, 153-161 (1996)

Cabala, J., Krupa, P., Misz-Kennan, M.: Heavy metals in mycorrhizal rhizospheres contaminated by $\mathrm{Zn}-\mathrm{Pb}$ mining and smelting around Olkusz in Southern Poland. Water Air Soil Pollut. 199, 139-149 (2009)

Čeburnis, D., Steinnes, E.: Conifer needles as biomonitors of atmospheric heavy metal deposition: comparison with mosses and precipitation role of the canopy. Atmos. Environ. 34, 4265-4271 (2000)

Fernándèz, J.A., Carballeira, A.: A comparison of indigenous mosses and topsoils for use in monitoring atmospheric heavy metal deposition in Galicia (northwest Spain). Environ. Pollut. 114, 431-441 (2001)

Fernándèz, J.A., Aboal, J.R., Carballeira, A.: Use of native and transplanted mosses as complementary techniques for biomonitoring mercury around an industrial facility. Sci. Total. Environ. 256, 151-161 (2000)

Gupta, S., Pandotra, P., Gupta, A.P., Dhar, J.K., Sharma, G., Ram, G., Husain, M.K., Bedi, Y.S.: Volatile (As and $\mathrm{Hg}$ ) and non-volatile $(\mathrm{Pb}$ and $\mathrm{Cd})$ toxic heavy metals analysis in rhizome of Zingiber officinale collected from different locations of North Western Himalayas by atomic absorption spectroscopy. Food Chem. Toxicol. 48, 2966-2971 (2010)

Guschina, I.A., Harwood, J.L.: Lipid metabolism in the moss Rhytidiadelphus squarrosus (Hedw.) Warnst. from lead-contaminated and non-contaminated populations. J. Exp. Bot. 53, 455-463 (2002)

Holoubek, I., Korinek, P., Seda, Z., Schneiderova, E., Holoubkova, I., Pacl, A., Triska, J., Cudlin, P., Caslavsky, J.: The use of mosses and pine needles to detect persistent organic pollutants at local and regional scales. Environ. Pollut. 109, 283-292 (2000)

ICP Vegetation: Heavy metals in European mosses: 2005/2006 survey. Monitoring manual. UNECE ICP Vegetation Coordination Centre, CEH Bangor, UK (2005)

Kabata-Pendias, A.: Trace elements in soils and plants. CRC Press, Boca Raton (2001)

Kolon, K., Samecka-Cymerman, A., Kempers, A.J., Mróz, L.: Pleurozium schreberi of the Tatra mountains (Poland) used as a bioindicational system for observing long range atmospheric transport of chemical elements. J. Atmos. Chem. 66, 157-166 (2010)

Kosior, G., Samecka-Cymerman, A., Kolon, K., Kempers, A.J.: Bioindication capacity of metal pollution of native and transplanted Pleurozium schreberi under various levels of pollution. Chemosphere 81, 321-326 (2010)

Markert, B., Herpin, U., Siewers, U., Berlekamp, J., Lieth, H.: The German heavy metal survey by means of mosses. Sci. Total. Environ. 182, 159-168 (1996)

Mersch, J., Reichard, M.: In situ investigation of trace metal availability in industrial effluents using transplanted aquatic mosses. Arch. Environ. Contam. Toxicol. 34, 336-342 (1998)

Michalska, A.: Analiza zanieczyszczenia środowiska rtęcią na terenie województwa śląskiego [Analysis of mercury content in the environment in the Silesian Voievodeship] [Engl. Summ]. J. Ecol. Health 14(4), 165-168 (2010) 
Migaszewski, Z.M., Gałuszka, A., Dołęgowska, S., Crock, J.G., Lamothe, P.J.: Mercury in mosses Hylocomium splendens (Hedw.) B.S.G. and Pleurozium schreberi (Brid.) Mitt. from Poland and Alaska: understanding the origin of pollution sources. Ecotoxicol. Environ. Saf. 73, 1345-1351 (2010)

Niemelä, M., Piispanen, J., Poikolainen, J., Perämäki, P.: Preliminary study of the use of terrestrial moss (Pleurozium schreberi) for biomonitoring traffic-related Pt and Rh deposition. Arch. Environ. Contam. Toxicol. 52, 347-354 (2007)

Pyta, H., Rosik-Dulewska, C., Czaplinka, M.: Speciation of ambient mercury in the Upper Silesia region, Poland. Water Air Soil Pollut. 197, 233-240 (2009)

Sardans, J., Peñuelas, J.: Trace element accumulation in the moss Hypnum cupressiforme Hedw. and the trees Quercus ilex L. and Pinus halepensis Mill. in Catalonia. Chemosphere 60, 1293-1307 (2005)

Shaw, A.J.: Adaptation to metals in widespread and endemic plants. Environ. Health Perspect. 102(Suppl. 12), 105-108 (1994)

StatSoft, Inc.: STATISTICA (data analysis software system), version 10. www.statsoft.com (2011)

Sztyler, A.: Relationships between aerosol optical depth and surface-layer extinction in the central part of the Upper Silesia industrial region over the period of 1983-1994. Atmos. Environ. 39, 1513-1523 (2005)

Zar, H.: In: Ryo, T. (ed.) Biostatistical analysis, 4th edn. Prentice Hall, Upper Saddle River (1999)

Zechmeister, H.G., Hohenwallner, D., Riss, A., Hanus-Illnar, A.: Variations in heavy metal concentrations in the moss species Abietinella abietina (Hedw.) Fleisch. according to sampling time, within site variability and increase in biomass. Sci. Total. Environ. 301, 55-65 (2003) 